\title{
Leaves as dining plates, food wraps and food packing material: Importance of renewable resources in Indian culture
}

\author{
Aruna Jyothi Kora(i)
}

\begin{abstract}
Background: The disposable plates made up of plastics such as polythene, polypropylene, polystyrene, polycarbonate, polyvinyl chloride, etc. pose health risks due to the release of toxic chemicals; bisphenol A, melamine, vinyl chloride, and phthalates. The usage of disposable plasticware not only depletes fossil fuels but also causes microplastics pollution. Thus, thrust has been shifted to utilization of disposable plates made from plant leaves, which are renewable, biodegradable, and enriched with antioxidants and medicinal values.

Results: In India, serving food on leaf dining plates is a long-standing tradition with its own cultural, religious, medicinal, and socioeconomic significance. The leaf plate stitching is a livelihood activity for tribal people in Odisha, Madhya Pradesh, Chhattisgarh, Andhra Pradesh, and Telangana states of India. The leaves and leaf plates are used for offering naivedyam to god during worship and distribution of prasadam to devotees. They are extensively used for serving food during marriages, religious festivals, community feasts, etc. The leaves from a vast variety of plants are used as dining plates, food wraps during steam cooking, grilling and frying of various dishes, and food packing material in India.

Conclusions: The biodegradable leaf plates have vast potential in international market, which should meet in terms of quality and design. To sustain the practice of using leaf plates and discourage plastic plates; necessary regulations should be imposed by the government and monitored through local governing bodies. In addition, school children and college students should be educated and motivated to realize the importance.
\end{abstract}

Keywords: Leaves, Leaf plates, Renewable, Food wrap, Packing material, Resources

\section{Introduction}

The disposable plates, cups, bowls, tumblers, spoons, bags, covers, sheets, films are made from plastics such as polythene, polypropylene, polyester, polyethylene terephthalate, polystyrene, polycarbonate, epoxy resins, polysulfone, polyvinyl chloride, polyvinylidene chloride, and melamine formaldehyde. These plastics can release toxic substances including bisphenol A, melamine, vinyl chloride, phthalates, etc. into the food during usage. For example, bisphenol A, a starting material for the synthesis of plastics such as polycarbonate, epoxy resins, and polysulfone, is a possible carcinogen and causes prostrate and breast cancers, insulin resistance, and heart diseases (Today 2017). It is classified as xenoestrogen and being

Correspondence: koramaganti@gmail.com

National Centre for Compositional Characterisation of Materials (NCCCM),

Bhabha Atomic Research Centre, ECIL PO, Hyderabad 500 062, India an endocrine disrupting chemical (EDC), it exhibits hormone mimicking properties and affects the male and female fertility in humans and animals. The compound melamine is toxic and causes kidney damage. Whereas, polystyrene, one of the most used plastics, is nonbiodegradable, photooxidation-resistant, cancer suspect agent, and also affects the thyroid hormone levels. The phthalates used as plasticizers to improve the flexibility, transparency and durability of polyvinyl chloride (PVC) are classified under EDC and affect hormone levels, male fertility and cause birth defects. They are also metabolic disruptors and possible carcinogens. The vinyl chloride monomer, a precursor to $\mathrm{PVC}$, is also a recognized human carcinogen. Notably, most of these plastics are produced from nonrenewable fossil fuels such as petroleum or natural gas, which are going to be exhausted with increasing demand and show definitive impact on human health and environment. The carbon emissions released 
from incineration of plastics such as dioxins and furans are toxic, carcinogenic and persistent organic pollutants (POPs). Another important aspect is the microplastics pollution in marine environment which is caused by durable, persistent, slow-degrading plastic fragments of less than $5 \mathrm{~mm}$ length; leading to its accumulation within the food chain of oceans and seas. They also act as a sink for other POPs surrounding them, while the ingestion of plastic bags and covers by stray cows and cattle leads to their accumulation in gut and causes subsequent death (https://en.wikipedia.org/wiki/Plastic 2018; Today 2017; Venkata Ramana 2018). It is alarming that India generates around 26, 000 tonnes of plastic waste a day and each Indian consumes $11 \mathrm{~kg}$ of plastic annually (Seetharaman 2019).

\section{Environmental importance of leaf plates}

The impact of disposable plasticware utilization in our day to day has led to a search for alternate renewable resource, i.e., use of plant leaves as dining plates and food wraps, a traditional practice in India. The long-standing tradition has its own cultural, religious, medicinal, socioeconomic importance in India. The leaves are one of the non-timers forest produce (NTFP) and collected from the forests by the tribal people of India. The plates and cups made out of leaves are known as patravali, pattal, vistari, vistaraku; and done, dona, respectively, in various Indian languages. The leaf plates are environment friendly, biodegradable, amenable for longer duration storage and can be easily disposed off. They are economical and don't require cleaning with phosphate-rich soaps and detergents, a time taking, labor intensive process. The nutrient-rich detergents released into the water bodies lead to a phenomenon known as eutrophication, in which excessive growth of algae and its anaerobic decomposition depletes dissolved oxygen leading to fish kill (Sarin, 2017). The leaves exhibit significant antibacterial and antifungal properties against various bacteria and fungi, thus protect us from the environmental and food borne pathogens (Sahu and Padhy 2013). The abundance of polyphenols, which could probably be leached into the food make them as ideal natural antioxidants (Somayaji and Hegde 2016).

\section{Leaf plate trade in India}

The normal steps involved in leaf plate making are leaf collection, leaf drying, hand or machine stitching into plates and bundling for transport. Usually, the leaf collection from nearby forests is done by women and far distance by men. But, the stitching work is carried out mostly by women at home. The plates are manufactured in small scale and cottage industries. The single-layered hand and sewing machine stitched plates known as khali are directly used by the consumers for dining purpose or further pressed into thick plates by heat pressing machines, which are procured by the commission agents, dealers and traders. The amenability of leaves to machine compression depends upon unfurling nature, fibrous content mechanical strength, type, and venation orientation of the leaves. Among the locally available resources, leaves from sal, addaku, and palasa are amenable for commercial leaf plate making. The pedaloperated and hydraulic heat pressing plate making machines perform the function of molding, trimming, pressing, and drying of the product. The machines are widely used in the states of Andhra Pradesh, Telangana, Odisha, Madhya Pradesh, and Chhattisgarh. The plates are made into water and leak proof by sandwiching a low-density polyethylene (LDPE)-binding layer in between the leaves and the underlying cardboard paper or leaves. The cardboard paper is generally made from cotton and old cloths. The leaf plates are available in the size of 11-18" diameter; cups and bowls in the size of 3-8" diameter; partitioned trays and buffet plates based on market and customer requirement, as there is no fixed standard set by the Bureau of Indian Standards (BIS). The cups are used for serving liquid food items such as soups, cereals, raita, and dal. Under Chapter 46, based on government decision, there is no levied goods and services tax (GST) on these products, which an indirect tax levied on the supply of goods and services in India. Moreover, the establishment of this industry does not require clearance from local pollution control agency such as State Pollution Control Board. For the regeneration of leaves and sustenance of forest cover, the state governments restrict the leaf collection to 4-6 months in a year. The age-old Indian tradition of leaf plates has attracted the attention of European market and a German company; Leaf Republic is manufacturing and importing both the finished goods and raw material by interacting with the local tribal people of India. The leaf scrap waste generated during the operation of the machines can be made into biodegradable paper by repulpation, which is cost-effective. (Leaf cups 2018; Raj 2018; Singh 2018; Tangar 2017; Vasundhara, 2018; Venkata Ramana 2018).

\section{Cultural and religious significance of leaf plates in India}

There are many ways of worshipping gods for Hindus, in which puja is the most popular form. The puja is performed by offering shodopachara, i.e., a standard system of 16 services to be executed to the god at temples and homes. Among the 16 services, offering naivedyam is one of the forms of expressing reverence and naivedyam is offered to the god either on a single broad leaf or plate made up of leaves (Tortora 2014). After offering the naivedyam to the deity, it becomes prasadam that is 
distributed on god's name to the devotees. It is a popular belief that eating prasadam cures the diseases and controls the wrongdoing acts of humans. According to Acharya Charaka, the leaves are extremely modest and during the practice of eating food on leaf plate with hands, the sparsh (touch) connects all the sense organs with mind. The practice of eating with hands by sitting on the floor is very apt for the present generation for controlling gastritis and obesity (Hegde et al. 2018).

The custom of serving meal on leaves and leaf plates is considered as pure and good practice during various occasions such as marriages and birth day; and free food offered during community feasts and religious festivals. For example, during dham, the food is served in leaf plates for people sitting in lines on the ground. The dham is a popular, traditional feast prepared during marriages and local festivals in Himachal Pradesh in which nutritionally rich food cooked in a traditional way is served. It symbolizes the universal brotherhood, as people seated in lines irrespective of their status during such traditional feasts (Tanwar et al. 2018). Also, in the month of Karthika and during Ayyappa deeksha, it is customary to use leaves and leaf plates for serving food. During deeksha period, the devotees offer naivedyam to god Ayyappa in leaf plates, take satvika (non-stimulating, energy providing) food served on leaf platters and distribute prasadam in leaf plates and cups. In olden days, the leaves are extensively used for packing breakfast, meals, and groceries and the practice is continued in villages even now.

\section{Varieties of plant leaves employed as plates, wraps, and packing material in India}

Plant and tree leaves belonging to a variety of families of the plant kingdom are used as single leaf plates, stitched dining leaf plates, food wraps, and food packing materials. The current review provides information on plant local names, their distribution, cultural and religious significance, medicinal values, biological properties, and applications of leaves with specific reference to dining, wrapping, and packaging.

\section{Shorea robusta}

It is known as sal, meaning house in Sanskrit language and saluva, dammar, and ral in other Indian languages. It is a large, deciduous, highly regenerating, high timber valued tree belongs to the family Dipterocarpaceae. It has religious importance for Hindus, Jains, and Buddhists. It is a native tree of Indian subcontinent and distributed in India, Myanmar, Nepal, Bangladesh, and Bhutan. It is extended in Odisha, West Bengal, Bihar, Jharkhand, Madhya Pradesh, Chhattisgarh, Haryana, Assam, Tripura, Andhra Pradesh, and Himachal Pradesh states of India. The leaves are of $10-25 \times 5-15 \mathrm{~cm}$ size and used in Ayurveda and Unani for treating ulcers, wounds, leprosy, earache, and headache. The leaves are rich source of various flavonoids and exhibit antiobesitic, anti-inflammatory, antinociceptive, antibacterial, antipyretic, analgesic, antihelminthic, alexiteric, and wound healing activities (Merish et al. 2014).

The fresh leaves are used for serving small snacks such as boiled lentils and the sun dried leaves are stitched together using grass stem sticks or sewing machine to produce leaf plates (khali) and leaf bowls (dona). The leaf plates are used for serving meals during domestic and ceremonial occasions. In the temple of Lord Jagannath located at Puri, Odisha, the mahaprasad is served to the devotees in sal leaf plates in Anand Bazar. The used plates serve as a meal for the goats and cattle roaming in the streets. The leaf cups are routinely used for serving prasadam to the devotees in temples; and also pani puri, chat, and ragda pattice at roadside eateries [Fig. 1(a)]. As the sal forest of Odisha occupies around 30\% of total sal forests in India, it is one of the revenue-generating activities for the landless, marginal, and forestdependent tribal people living in the Sundargarh, Mayurbhanj, Kendujhar, Kandhmal, Debagarh, Nayagarh, Balasore, and Sambalpur districts of Odisha. Due to the absence of legal restrictions, round the year leaf availability, and occurrence of traditional knowledge in leaf plate making, the local people adopted this occupation, as a source of income. The final product, i.e., machine pressed plates are exported to the states of Andhra Pradesh, Bihar, West Bengal, Telangana, Madhya Pradesh, Karnataka, Maharashtra, and Gujarat through railways and roadways (Dash 2015; Singh 2018; Vasundhara, 2018).

\section{Phanera vahlii}

The plant is known with local names addaku, madapaku, and siali in different Indian languages. It is a giant, wild, woody, perennial climber belongs to the family Caesalpiniaceae, a native tree of Indian subcontinent; India, Nepal, Myanmar, Thailand, China, Vietnam, Laos, Cambodia, and Pakistan. It is widely distributed in the forest areas of Indian states such as Odisha, Andhra Pradesh, West Bengal, Telangana, Karnataka, Tamil Nadu, Maharashtra, Bihar, Uttar Pradesh, Madhya Pradesh, Rajasthan, Punjab, Haryana, Uttarakhand, Sikkim, Assam, Arunachal Pradesh, Nagaland, Manipur, Mizoram, Meghalaya, Himachal Pradesh, and Jammu and Kashmir. The leaves are bilobed, $10-46 \mathrm{~cm}$ long, rich in various quercetin flavonoids and known to exhibit antibacterial, antimicrobial, antioxidant, anti-inflammatory, and antidiabetic effects [Fig. 1(b)] (Chouhan and Saklani 2013).

The shade dried leaves in 4-5 numbers are hand and machine stitched into round plates using grass stem sticks and thread, respectively [Fig. 1(c-d)]. These leaf plates are extensively used as meal plates in houses, 


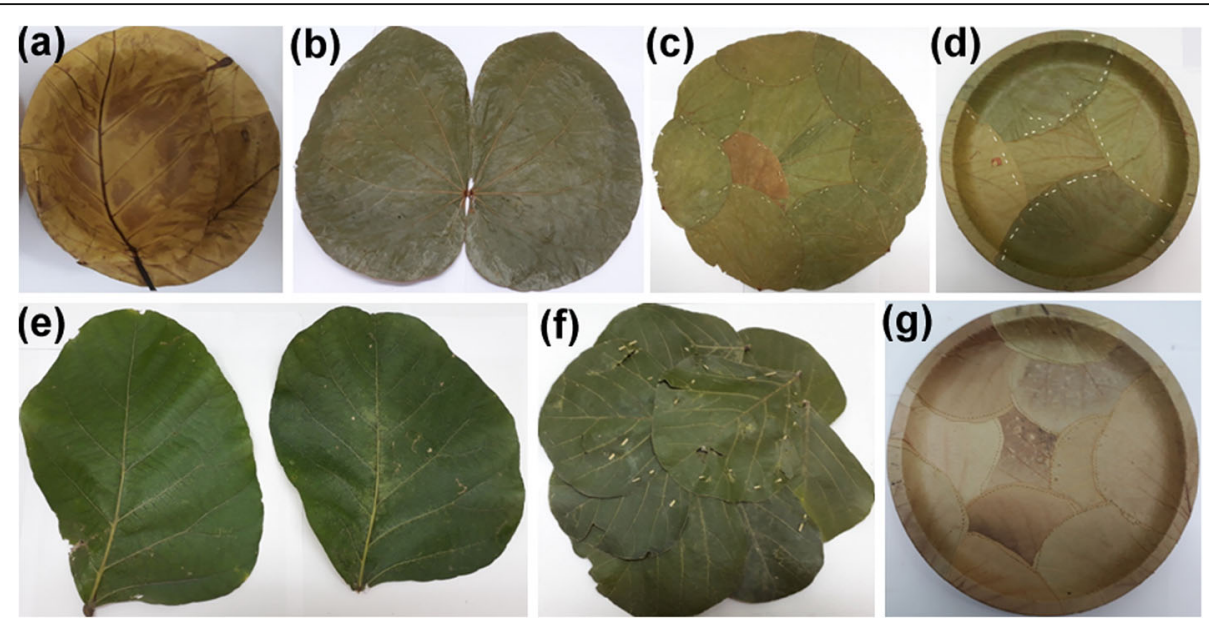

Fig. 1 a The machine compressed cup made from the leaves of sal, S. robusta, (b) the bilobed leaf of addaku, P. vahlii, (c) the hand stitched and (d) machine compressed dining plates made from the leaves of addaku, (e) the leaves of moduga, B. monosperma, (f) the hand stitched and (g) machine compressed dining plates made from the leaves of moduga

hotels, and religious ceremonies, festivals, weddings, community feasts and also in occasions where food is served for a large number of people (Chouhan and Saklani 2013). It is common a practice in villages to use the leaves as packing material for cooked food such as idli, sweets like jilebi; and meat in small hotels and butcher shops, respectively. The cone-shaped leaf wraps are used during the steam cooking of millet flour idli, named as vasenapoli at the local eatery outlets of Visakhapatnam city of Andhra Pradesh state. The food wraps not only enhances the aroma of the steam cooked food but also the shelf life (Raju 2018). They are also made into cups and bowls for serving the liquid foods such as soup, dal, and ice cream. In Kurnool district of Andhra Pradesh state, the hand oven cups are often used for serving honey along with sajja rotte by the Chenchu tribes of Nallamala forest at the roadside eateries. The sale of prasadam such as godhuma ravva kesari in addaku leaf packing is a traditional and continuing practice at the temple of Sri Satyanarayana Swamy located at Annavaram, Andhra Pradesh (http://annavaramdevasthanam.nic.in/prasadam.htm 2018).

In Odisha state, the plate making activity with siali leaves is one of the most important socioeconomic activities for the people in the forest villages of Kandhamal, Koraput, Malkangiri, Rayagada, Angul, and Debagarh districts. It is especially a means of subsistence for the rural women in tribal dominated districts of Odisha and Paderu forest division of Visakhapatnam district of Andhra Pradesh. In comparison with sal, siali leaves are the preferred raw material due to the large size and durability of the leaf. As the leaves are critical source of the income, the tribal people protect and nurture the siali climbers. Some of the non-governmental organizations (NGOs) such as Pradan, etc. are collating the makers as self-help groups and forming cooperative societies for increasing the income of the local village tribal people by ensuring higher profit margins. It is done by providing training, technology; market linkages with wholesale buyers and upgrading product quality. The finished product is exported by the wholesalers to other states such as Maharashtra, Gujarat, Andhra Pradesh, Madhya Pradesh, Tamil Nadu, Karnataka, Rajasthan, and Chhattisgarh. It is estimated that sal and siali leaf trade in Odisha is around Rupees 400 crores every year (Sahu 2015; Shriya 2009). Based on the Paris agreement on climate change, the developed nations in Europe are shifting to biodegradable products. As a part of this initiate, high-end restaurants are serving food to their customers in biodegradable siali pates, sourced from tribal women of Odisha by Leaf Republic (Abraham, 2016).

\section{Butea monosperma}

It is known as flame of the forest and moduga, palasa, and palash in various Indian languages. It is a medium sized, deciduous, drought, and frost-resistant tree; adapted to grow extensively in poor soils of open plains, grasslands, and wastelands in the dry seasons. It belongs to the family Fabaceae, a native tree of tropical and subtropical climate of Indian subcontinent and Southeast Asian countries such as India, Sri Lanka, Bangladesh, Nepal, Myanmar, Thailand, Cambodia, Vietnam, Malaysia, and Indonesia. In India, it is abundant in the states of Jharkhand, Andhra Pradesh, Telangana, West Bengal, Maharashtra, Kerala, and Punjab. It is a sacred tree for Hindus and Buddhists, and the leaves are trifoliate, pinnate, and 10-15 cm long [Fig. 1(e)] (Prasad et al. 2006). The various parts of the tree such as leaves, stem, bark, flowers, gum, and seeds are extensively used in Ayurveda due to their medicinal values. The leaves 
are known to possess myriad of properties such as antihelminthic, antidiarrheal, antidiabetic, antihyperlipidemic, anti-inflammatory, antiulcer, antitumor, antibacterial, antifungal, antimicrobial, antioxidant, antifilarial, anticonvulsant, antinociceptive, anticlastogenic, antistress, antiamnesic, nephroprotective, wound healing, and sunscreen activities. The leaf blades are employed as tonic, diuretic, appetizer, carminative, astringent, noortropic, and aphrodisiac agents. It is also utilized for the treatment of various ailments including elephantiasis, eye diseases, skin disorders, stomach disorders, flatulent colic, irregular menstrual bleeding, hemorrhoids, diabetic sore throat, cough, cold, etc. The leaves are enriched with various biomolecules such as glycosides, steroids, flavonoids, alkaloids, tannins, polyphenols, starch, carbohydrates, and proteins; and linoleic, oleic, palmitic, and lignoceric acids (Mengi and Deshpande 1999; Sahu and Padhy 2013; Somayaji and Hegde 2016).

In the states of Odisha, Maharashtra, Andhra Pradesh, and Telangana, the plates (vistari) and cups (dona) made of dried leaves are widely used for serving food and meals for people during rural feasts and also offering naivedyam to various gods and distribution of prasadam to deities during festival and religious ceremonies [Fig. $1(\mathrm{f}-\mathrm{g})]$. It is believed that by eating the food served on moduga leaves keeps the person away from liver disorders, skin diseases and cancer (Today 2017). The tribal people from the Adilabad district of Telangana state prepare the handmade, wheat dough rotis on these leaf surfaces and offer in as naivedyam in moduga leaves to the worshipping god Bheemanna, a principal deity of the tribe. The grilled rotis are considered as prasadam and eaten by the tribals in the forests as vana bhojanam. Such practice of grilling bread on moduga leaves, offering to god and eating cooked rice, and drinking water in moduga leaves is followed throughout the month of April, as they considered it as a healthy way of living (Prasad 2018). The leaves also serve as a packing material for closing the side of bamboo stick during the grilling of bongu chicken, a cholesterol-free chicken dish prepared by the tribes of Visakhapatnam district of Andhra Pradesh state. It is important to note that the nutrient-rich, leathery leaves are good fodder for buffaloes. The tree is known to improve the soil fertility by increasing the soil organic carbon via faster decomposition of nutrient-rich leaf litter. It is one of the main host trees for the lac insect (Laccifer lacca) and pruned trees are the ideal candidates for lac cultivation. Hence, the leaf plucking is done in an environment-friendly process without causing damage to the tree (Rai et al. 2016).

\section{Areca catechu}

It is known as areca palm, areca nut palm, beetle nut palm in English, and vakka, adakka, adike, puga, supari, pakku, kamugu, and gua in various Indian languages. It is a medium-sized, single-trunked, tropical palm with a slender, erect, unbranched solitary stem and belongs to the family Aracaceae. It has widespread cultivation in China, India, Bangladesh, Sri Lanka, Malaysia, Thailand, Vietnam, West Indies, and Indonesia. The leaves are long and palmate and sized around $1.5-2 \mathrm{~m}$. The sheaths of the leaves encircle the stem by forming a protective layer around it. The sheaths are oblong in shape and have varying length of $65-111 \mathrm{~cm}$, width of 23-33 $\mathrm{cm}$, and thickness of $2.5-5.25 \mathrm{~mm}$ [Fig. 2(a)]. The sheaths exhibit good tensile strength and low calorific value and composed of cellulose, hemicelluloses, lignin, pectin, and fiber. The wet sheaths are used as an alternative fodder for cattle, while the dry sheaths are used as fire wood by the farmers. The trees are usually grown in the hilly areas without any input of fertilizer and pesticides. The leaf sheaths abundantly available in the states of Kerala, Tamil Nadu, and Assam are used for making disposable plates and cups [Fig. 2(b)]. The naturally fallen, thick sheaths are collected; water washed, soaked in hot water, and hot compressed to fabricate plates and cups. Among the other leaf plates, they are rigid, dense, heat-tolerant, and high quality. They are leak proof,

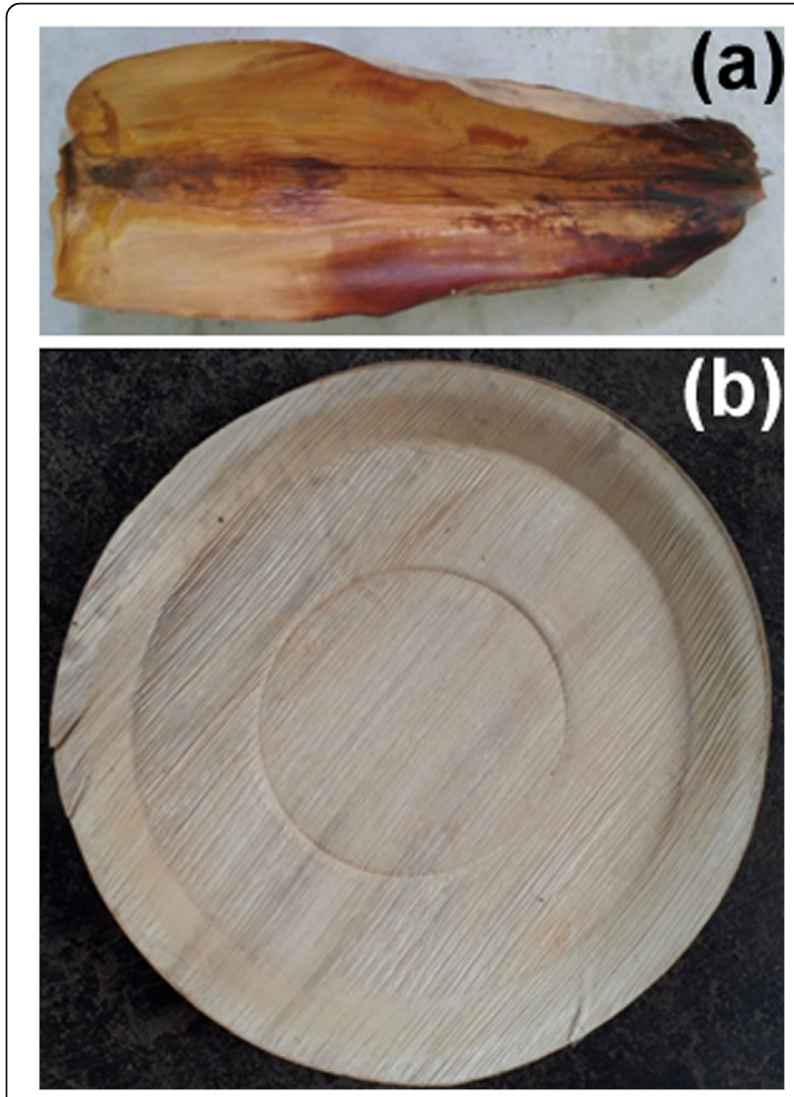

Fig. 2 a The leaf sheath of vakka, A. catechu and (b) the machine compressed dining plate made from the leaf sheath of vakka 
water resistant, odorless; freezer, microwave, and oven safe; naturally biodegradable and compostable. In terms of food safety, they are safe to use with moist food for single use and for multiple times for dry food. The leaf plates and cups are also used for holding cold and hot liquids, as they exhibit thermal resistance and shape rigidity. In addition, they are durable, appear wood like as the texture of the plate provides esthetic and natural look and used for outdoor occasions such as picnics (Goyal, 2018; Selvakumar, 2018; Shashikumar et al. 2016).

\section{Musa $\times$ paradisiaca}

The banana plant is known as kadali, arati, and kela in several Indian languages. It is a tropical, cormed, pseudo stemmed, herbaceous plant belonging to the family Musaceae. It is native to Indo-Malaysia; and Australia, India, and China are the largest producers of banana in the world. It is regarded as kalpataru, a plant with all virtues due to the multipurpose use of all its parts. The leaves are large, flexible, water proof, and sized around $2.7 \times 0.6 \mathrm{~m}$ [Fig. 3(a)]. The leaves are rich source of polyphenols, flavonoids, fiber, carbohydrates, tannins, vitamin $C$, enzymes, and potassium. The leaves show antioxidant, antidiabetic, aphrodisiac, antibacterial, antifungal, and anticancer activities. It is reported that the leaves purifies blood, boosts immune system, stimulates appetite, aids in food digestion, chlorophyll soothes the mucus lining, prevents from intestinal ulcers, and protects from skin diseases. The leaves are used for treating skin problems such as wounds, rashes, irritation, eczema, dandruff, sun burn, poisonous insect bites, bee stings, spider bites, cough, bronchitis, hyper tension, gout, kidney stones, bladder-related diseases, piles, and heart diseases. The leaf blades are also used as dressing material for covering the body surfaces of burn wood patients due to its cooling effect (Hegde et al. 2018; Imam and Akter 2011; Swathi et al., 2011; Today 2017).

In India, serving food or meal on banana leaf is a longstanding unique tradition, especially in the southern states of Tamil Nadu, Karnataka, Kerala, Andhra Pradesh, and Telangana. It is a healthy, traditional, and auspicious practice to serve meal on banana leaves during festivals, family functions, weddings, traditional feasts, and religious occasions. The banana leaves are the favorite as dining plates among other due to the abundance of polyphenols, which act as antioxidants and help in digestion of the food by emanating its ingredients such as vitamin $\mathrm{C}$ and potassium during hot food serving. Most importantly, the large blade size of the leaf accommodates multi course meal such as rice, curries, chutney, pachadi, sweet dish, etc. The inexhaustible leaves are water and leak proof; free from detergent residues and provide specific flavor and aroma after serving the steamy food. Moreover, the disposed biodegradable leaves are favorite meal for cows and buffalos. The meal served on banana leaf should be eaten with hands by sitting on the floor, which is traditional way during vindu bhojanam and sadhya, a banquet served during marriages and festive and ceremonial occasions. In some of the restaurants in Tamil Nadu and Karnataka, it is mandatory to serve the food on banana leaves. During the festival of Ganesh Chaturthi, people from Maharashtra eat food served on banana leaves. Most importantly, the practice is considered sacred by offering naivedyam on banana leaves to various gods and goddesses [Fig. 3(b)]. The leaves are often used to distribute prasadam to devotees, a

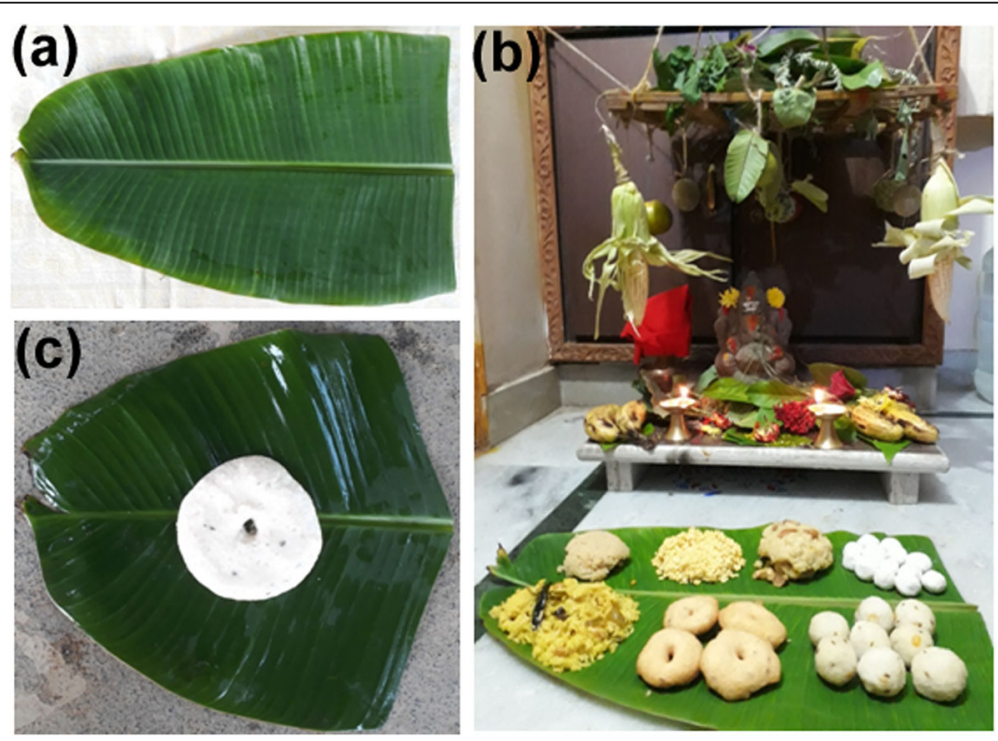

Fig. 3 a The leaf of banana, M. paradisiaca, (b) naivedyam offered to god Ganesha on banana leaf during the festival of Ganesh Chaturthi and (c) the utilization of banana leaf blade as a non-adherent surface for spreading the batter of gaare before oil frying 
common practice in Hindu temples. Notably, the mahaprasad of Lord Jagannath, Puri should be eaten sitting on the floor, served on banana leaf, which is regarded as a golden plate. The large and flexible leaves are amenable for cutting, and blades of different sizes are used as plate liners and table decors. The leaves are used as packing material for cooked food such as rice, as they seal the moisture and flavor of the food by acting as a foil, for example, pothichoru, a parcel of take away meal in which many dishes are typically covered in blanched banana leaves, which can be consumed latter. In olden days, it is a traditional practice of carrying pothichoru to schools, colleges, and offices in Kerala, when lunch boxes are not popular. Also, packing of parotta and chicken and mutton curry in banana leaves is a practice in some restaurants in Kerala. The local flower sellers also use them for packing flowers by tying with natural plant fibers. The leaf cones are used for serving savories, salads, cooked lentils, and roasted pulses. The leaves are also used as wrappers for food that can be steamed, baked, roasted, and grilled, in which the packed ingredients are protected from the direct flame burning along with flavor addition from the leaves. They are used as wrappers during the steam cooking of elayada, a traditional sweet dish from Kerala. In West Bengal, the leaves are used during steam cooking and grilling of macher paturi, in which marinated and seasoned boneless fish is wrapped inside a banana leaf. Sometimes, they are also used as fresh, organic frying pans while making thath bakri, a Mangalorean catholic cuisine and also used as a wrap during the roasting of rice panki, a savory from Gujarat. The leaves are used as a nonadherent surface for spreading the batter of gaare before oil frying [Fig. 3(c)]. The dried leaves are used for food packing and making cups to hold liquid foods. In West Bengal, the leaves of banana is an essential part of Navapatrika (9 leaves), which are worshipped during the Saptami day of Navaratri Durga Puja festival, representing the nine different forms of goddess Durga. Among the 9 leaves, the banana leaf represents goddess Brahmani (Hegde et al. 2018; Rajkumar, 2014; Sarin, 2017; Tankha, 2002; Today 2017)

The production of banana leaves as dining plates is commercial trade in the states of Tamil Nadu, Karnataka, Kerala and Andhra Pradesh, as a result of standardized practices and organized marketing channels. The estimated annual turnover of the leaf industry is about Rupees 100 crore. It has gained importance mainly due to its traditional, cultural, religious, and ecological value; yearlong continuous demand for the leaves, sustained income source for many marginal farming families, ability to act as a buffer during the price fluctuation in fruit trade, and the applicability to garden, wet and high land production systems. The main plant crop is for the bunch production, whereas the first and second ratoons are used for leaf harvesting purpose. Usually the dual purpose, commercial cultivars used is poovan, monthan, peyan sakkai, and karpuravalli. Also, considerable research on germplasm has been done at National Research Centre for Banana (NRCB), Tiruchirappalli for recognizing and developing banana varieties with desirable characters such as (i) production of large number of quality leaves in given span of time, (ii) production of soft and flexible leaves, (iii) generation of marketable quality leaves free from leaf spot diseases, and (iv) profuse suckering habit. Based on these criteria, the cultivars NRCB selection-1, borkal basta, and elaivazhai were proven to be the suitable varieties for the leaf industry. The cultivar elaivazhai is a wild, diploid, nonedible, seeded variety originated from Musa balbisiana, grown extensively in the backyards of rural households in Western Ghats of Karnataka, Kerala and Tamil Nadu for dining plates in daily life, while the borkal basta is another promising high yielding, backyard cultivar from North-East states of India (Uma 2008; Uma et al. 2018).

\section{Nelumbo nucifera}

The lotus plant is known as tamara, kamal, padma, pankaja, etc. in various Indian languages. It is an aquatic, perennial herb that belongs to the family, Nelumbonaceae. It is considered as sacred water lily in Hindu and Buddhist religions. It is a native plant of India, Sri Lanka, China, Japan, and Vietnam and widely distributed in Russia, New Guinea, and Australia. In India, its distribution ranges from central, northern, to southern India. The lotus flower is the national flower of India and Vietnam. The leaves are peltate, circular in shape; size varies from $20-90 \mathrm{~cm}$ in diameter and found as floating or aerial blades in water bodies such as ponds, lakes, and water gardens [Fig. 4(a)]. The leaves exhibit ultra-hydrophobicity, popularly known as lotus leaf effect due to the presence of dense, waxy cuticle layer on the leaf surface. According to Karma Sanyasa Yoga described in Chapter 5 of Bhagavad Gita, the leaf is considered as a symbol of purity and sanctity due to its selfcleaning, water proofing, and hydrophobic properties. The leaves contain various alkaloids, flavonoids, steroids, and glycosides and exhibit various activities such as antibacterial, anti-HIV, antifungal, anticancer, antidiabetic, antiobesitic, anti-inflammatory, antimalarial, antimutagenic, antioxidant, antipyretic, antispasmodic, aphrodisiac, astringent, cytoprotective, hepatoprotective, hypolipidemic, hypotensive, and expectorant properties. According to Sutrasthana, the first chapter of Charaka Samhita, the fresh leaves are known to possess coolant, bitter, diuretic, and astringent activities. Being a coolant, it is used for burning sensation removal during the swedana, sweating treatment. Also, in Ayurveda, it is utilized for treating excessive thirst, dysuria, piles, fistula, fatty liver, bleeding disorders, 

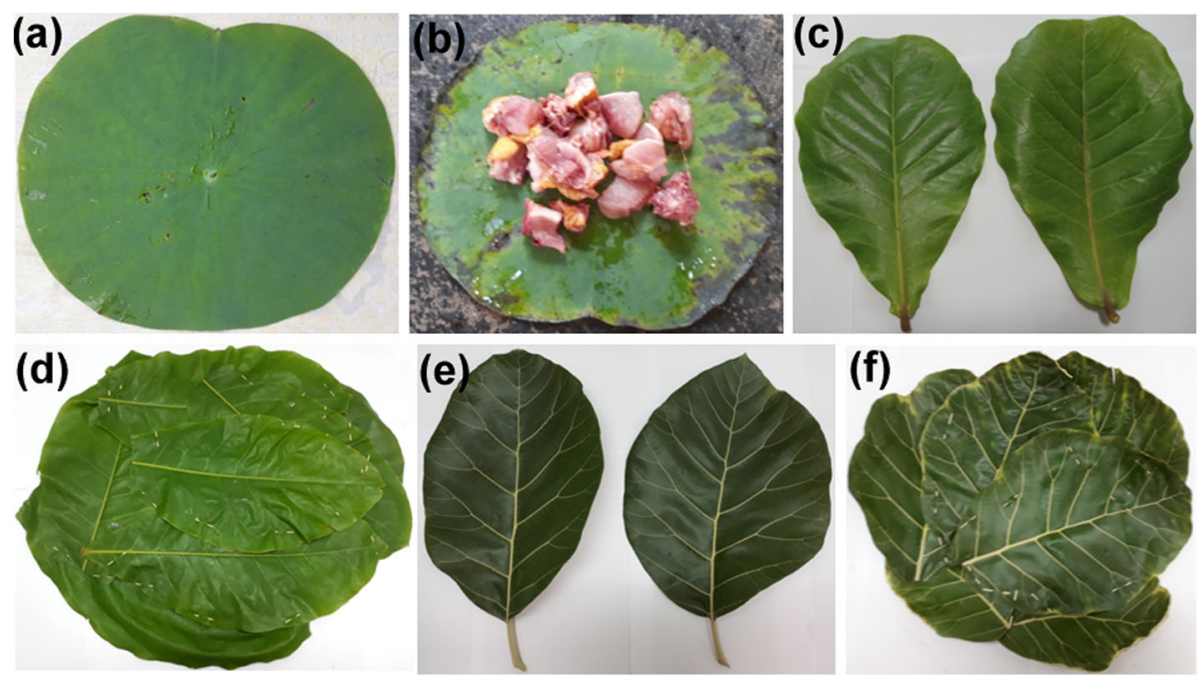

Fig. 4 a The leaf of lotus, N. nucifera, (b) the application of lotus leaf for packing meat, (c) the leaves of Indian badam, T. catappa, (d) the hand stitched dining plate made from the leaves of Indian badam, (e) the leaves of teku, T. grandis and (f) the hand stitched dining plate made from the leaves of teku

and blood detoxification (Hebbar 2015). The leaves are used as wrappers during steam cooking and wrapping the food ingredients attaches a distinctive flavor, earthy aroma, and taste to the dish via infusion of the leaf contents. The fresh and dried lotus leaves are also used for offering naivedyam to gods. The leaves are used a wrapper for the cooked food and packing meat, sweets, and flowers [Fig. 4(b)] (Mishra, 2014). The leaf powder acts as an oxidation retardant during the refrigerated storage of cooked food (Choe et al. 2011).

\section{Terminalia catappa}

The Indian almond is a medium sized, tropical tree that belongs to the family of Combretaceae and known as badam in various Indian languages. It is native to tropical areas such as Asia, Australia, and Africa. The ovoid shaped leaves are $15-25 \mathrm{~cm}$ long and abundant in various polyphenols, flavonoids, tannins, saponins, and phytosterols [Fig. 4(c)]. The leaves are known for their anti-inflammatory, antibacterial, antifungal, antiviral, antioxidant, antidiabetic, anticancer, anticlastogenic, and hepatoprotective properties. In Indian folk medicine, the leaves are used for dressing rheumatic joints and curing various skin ailments such as scabies, leprosy; diarrhea, and fever (Muhammad and Mudi 2011; Terças et al. 2017). The fresh leaves are hand stitched into plates and used for serving food [Fig. 4(d)]. In olden days, making plates out of badam leaves is a leisure time hobby for women in villages to generate revenues. As the leaves symbolize energy, eating food in these plates protects the persons from kidney, liver, and throat disorders. They are also employed as food wraps during steam cooking of badam leaf $k u d u b u$, a recipe from Udupi cuisine of Karnataka state (Today 2017).

\section{Tectona grandis}

It is known as teku, tekku, sagun, sag in various Indian languages. The teak is a large, tropical, hardwood, deciduous tree that belongs to the family Lamiaceae and naturally distributed in the Indian subcontinent; Myanmar, Sri Lanka, Indonesia, Malaysia, Bangladesh, and Thailand. It is abundantly distributed in the states of Tamil Nadu, Karnataka, Kerala, Odisha, Madhya Pradesh, Jharkhand, Maharashtra, Rajasthan, Bihar, and Telangana. The leaves are large, rough, broadly ovate to elliptic and sized around 8-60 $\times$ $15-30 \mathrm{~cm}$ [Fig. 4(e)]. The leaf extract is extensively used in folklore medicine for curing burn wounds; and alleviating vata and kapha; and for treating ascites, abdominal tumors, and dyspnea. The leaves contain carbohydrates, protein, crude fiber, calcium, phosphorous, dyes, alkaloids, tannins, saponins, and sterol and exhibit antibacterial, antiheamolytic anemic, antioxidant, diuretic, wound healing, slimming, and gastroprotective activities (Hegde et al. 2018; Nidavani and A, 2014; Sachan et al. 2014). The teak leaf cups are used for serving liquid food items such as soups, cereals, raita, and dal. The leaves are also used as plates for serving food to the agriculture labor engaged during farming activity in Prakasam district of Andhra Pradesh [Fig. 4(f)]. The leaves are also used as food wraps for specific color and aroma impartation during the steam cooking of jackfruit idli known as pelakai gatti, a sweet dish made in the costal districts of Dakshina Kannada and Udupi of Karnataka state (Culinary creations-Jackfruit idli, 2018).

\section{Pterospermum acerifolium}

It is commonly known as kanak champa in various Indian languages, due to its large sized, nocturnal, white colored, extremely fragrant flowers which attract pollinating moths. 
It is a tropical, ever green, ornamental, landscaping tree that belongs to the family Sterculiaceae, a native tree of Indian origin and found in Myanmar, Thailand, Philippines, and Java. It is distributed in the states of Himachal Pradesh, Chandigarh, Delhi, Madhya Pradesh, Odisha, West Bengal, Sikkim, Meghalaya, and Manipur. In folk medicine, the leaves are used for treating wounds, itches, fever, menorrhagia, and puerperium. The leaves are simple, very broad, peltate, shallow lobed, palmately ribbed, and sized around $40 \times 40 \mathrm{~cm}$. They resemble either maple leaves or elephant pugmark shape. Notably, the broad and dense leaves release the maximum amount of oxygen into the atmosphere. The leaves contain various bioactive molecules such as glycosides, flavonoids, tannins, steroids, triterpenes, saponins, and alkaloids and demonstrate various properties such as anti-inflammatory, antidiabetic, antimitotic, antioxidant, antihelminthic, anticancer, and hepatoprotective activities. The leaves are used for serving food, making disposable plates, packaging and storing material, and fodder. They are also woven into dinner plates and bowls either by stitching with twigs or molding. Because of its large sized leaf blade, it earned the name dinner plate tree. They are also used for reinforcement and leakage prevention of roofs, and as tinder for lighting fires (Chatterjee et al. 2012; Kapoor, 2018).

\section{Artocarpus heterophyllus}

It is known as panasa, chakka, phanas, etc. in various Indian languages. The jackfruit is medium sized to large, evergreen, native tree of South and Southeast Asia and originated from the rainforests of Western Ghats of India. It belongs to Moraceace family and cultivated in the countries including India, Bangladesh, Myanmar, Thailand, Nepal, Vietnam, China, Philippines, Indonesia, Malaysia, and Sri Lanka. In India, it is widely cultivated in the states of Kerala, Tamil Nadu, Karnataka, Andhra Pradesh, Assam, Tripura, Bihar, and Uttar Pradesh. The plant parts such as leaves, latex, bark, stem, inflorescence, and seeds are used in traditional medicine. The elliptical shaped leaves are 4-25 cm in length, acutely tipped, leathery [Fig. 5(a)] and utilized for the treatment of asthma, ringworm infestation, cracked heals, diabetes, gall stones, etc. They are known to induce lactation in women and domestic animals. The phylloplanes exhibit a myriad of activities including antibacterial, antifungal, antimicrobial, anticariogenic, antisyphilitic, antidiabetic, wound healing, antihelminthic, and dye adsorption properties. The leaves are the favorite feed for cattle and other livestock. The fresh leaves are stitched together to make round, single use, disposable plates [Fig. 5(c)]. The habit of eating food on jackfruit leaf plates enhances digestion of the taken food and relieves the pitta dosha from the body. Also, the leaves are used as a wrapping in the form of hand woven baskets for steam cooking of panasa buttalu, Andhra pottikkalu, kottekkalu, idli, kotte kadubu, and kumbilappam [Fig. 5(d-e)]; and casing material for baking dishes in the states of Karnataka, Goa, Kerala, Andhra Pradesh, and Maharashtra. In Kerala, the leaf cones known as plavila kori are also used as spoons for drinking kanji, a rice starch soup [Fig. 5(b)] (Sidhu 2012; Today 2017).

\section{Ficus bengalensis}

The banyan tree is commonly known as vata, bar, etc. in various Indian languages. It is a large, hardy, evergreen, drought resistant, fig tree; characterized by aerial prop roots and belongs to the family Moraceace. It is considered as a scared tree by the Hindus in India, and often, shrines and temples are constructed beneath the tree. Due to its characteristic longevity, it is considered as immortal and exemplified as a symbol of eternal life, peace, and harmony. Due to its large sized canopy, it is grown in temples, gardens, and roadsides to provide shade for visitors, community worship, and cultural activities. It was planted in large numbers by the kings along the pilgrimage and trade routes for shade and shelter to the pilgrims and distance travelers. It acts as a rural establishment by providing a peaceful environment for human interactions, village meetings, and government announcements. The national tree of India is endemic to India, Pakistan, Bangladesh, and Sri Lanka. It is found throughout the India from sub-Himalayan region to deciduous forests of Deccan and south India. Various plant parts such as bark, fruits, aerial roots, vegetative bubs, leaves, prop roots, and latex are extensively used in the prevention and treatment of different disorders in indigenous system of medicine; Ayurveda, Siddha, Unani, and homeopathy. The leaves are leathery, stout, entire, ovate to elliptic, $10-20 \times 8-20 \mathrm{~cm}$, apex obtuse, stalked, and reticular pinnately venated [Fig. 6(a)]. The leaves contain various flavonoids, terpenoids, and triterpenes and used for treating ulcers, leprosy, skin allergies, abscesses, diarrhea, hemorrhages, bleeding piles, fevers, dysentery, etc. The leaves show astringent, antibacterial, anti-inflammatory, antipyretic, analgesic, antioxidant, hypotensive, and wound healing activities. The leaves are used for making disposable plates and wrapping food [Fig. 6(b)]. It is also one of the host trees for the lac insects (Chaudhari et al. 2014; Chaudhary et al. 2015; Kothapalli et al. 2014;; Vora, 1969).

\section{Ficus religiosa}

The sacred fig is known as aswatha, bodhi, bo, peepal, and raavi in various Indian languages and belongs to the family Moraceace. It is a large, perennial, fast-growing, long-living, highly adaptable, widely branched, season deciduous, or semi ever green tree and native to Indian subcontinent and Indo-China. It is one of the sacred trees worshipped by Hindus, exemplified from the 

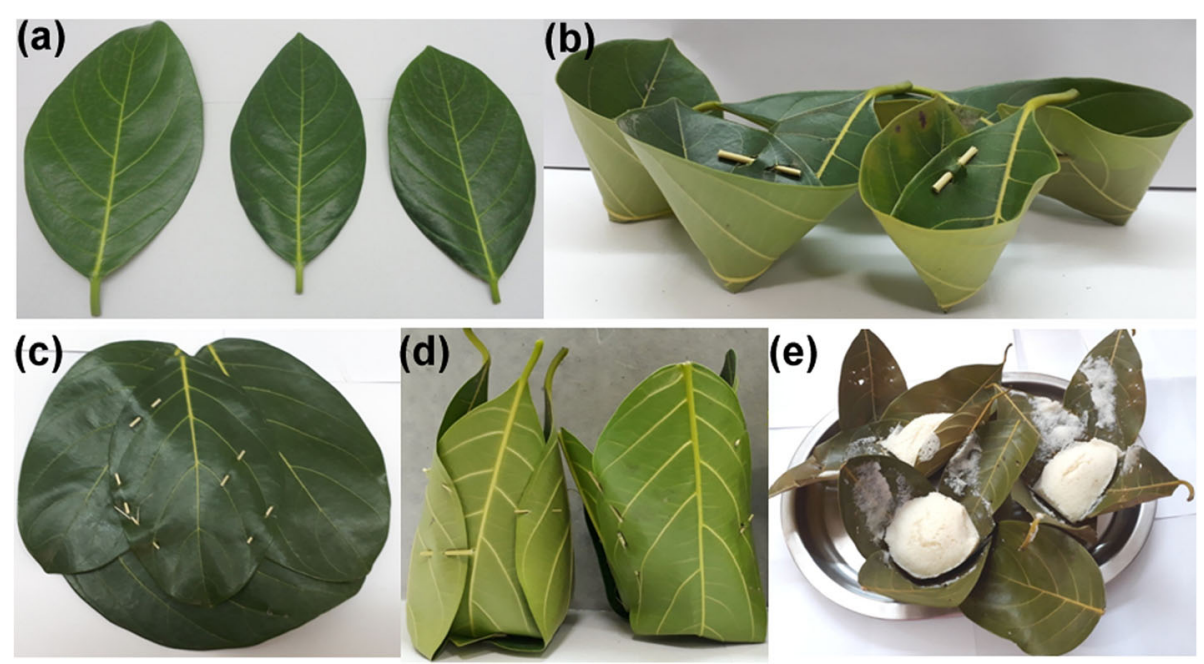

Fig. 5 a The leaves of jackfruit, A. heterophyllus, (b) the cones, plavila kori made with the jackfruit leaves are used as spoons for drinking kanji, (c) the hand stitched dining plate made from the leaves of jackfruit, (d) the hand woven jackfruit leaf baskets, panasa buttalu and (e) the steam cooked Andhra pottikkalu in leaf baskets.
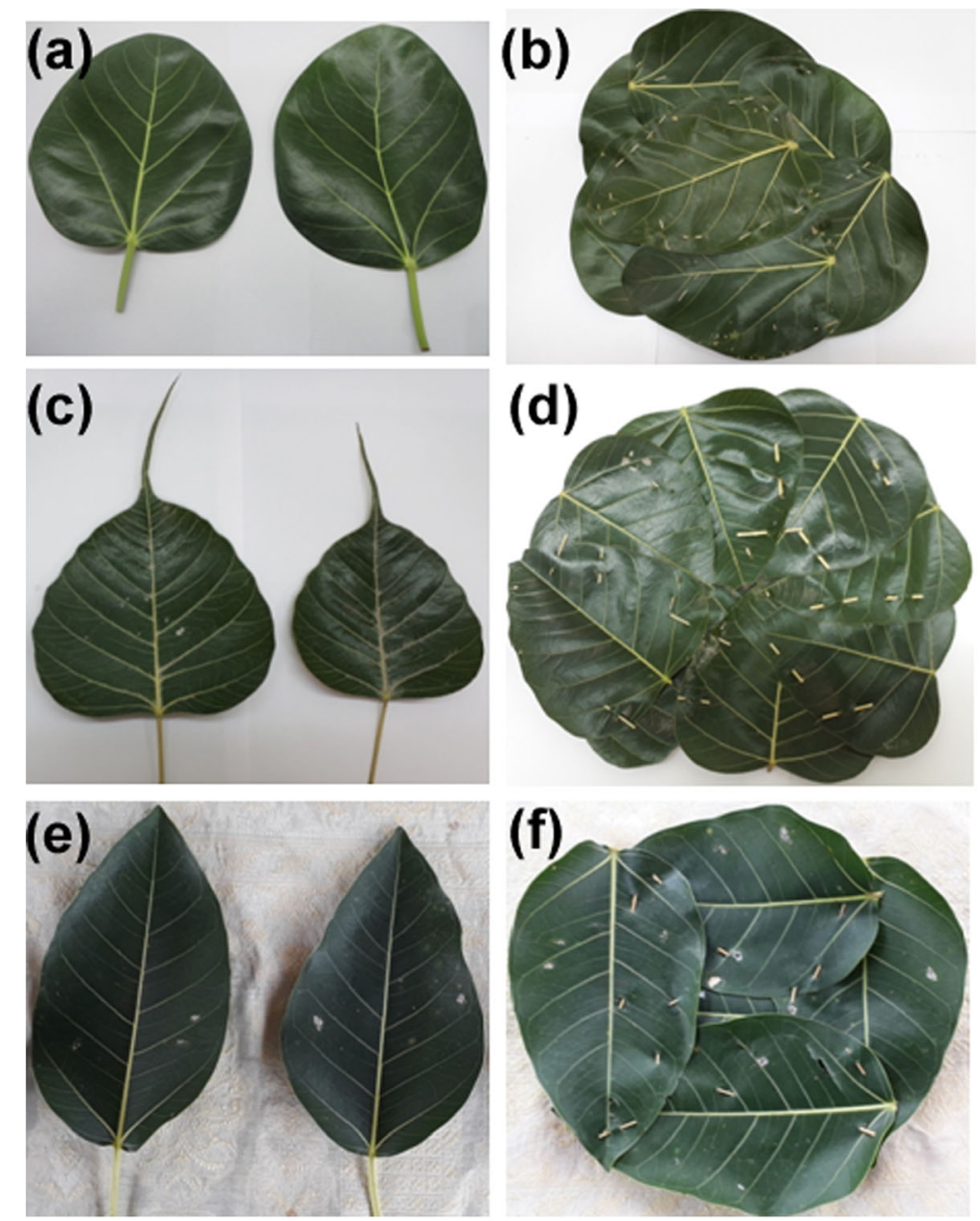

Fig. 6 a The leaves of banyan, F. bengalensis, (b) the hand stitched dining plate made from the leaves of banyan, (c) the leaves of aswatha, F. religiosa, (d) the hand stitched dining plate made from the leaves of aswatha, (e) the leaves of juwi, F. virens and ( $\mathbf{f}$ ) the hand stitched dining plate made from the leaves of juwi 
discovered seal at Mohenjo-Daro city of Indus valley civilization (3000-7000 BC). As a mark of worship and salutation, Hindu and Jain Sadhus meditate beneath the tree, and Hindu devotees perform pradakshina around the tree, as it is the king of all trees. The tree is a habitat for birds, insects and provides shade to humans and animals. It is a sacred fig for Buddhists, as Gautama Buddha attained the enlightenment (Buddha) while meditating underneath the tree. It is believed as a sign of enlightenment, peace, prosperity, longevity, happiness, and good luck. The plant parts such as roots, bark, latex, leaves, fruits, and seeds have various medicinal values. The leaves are shiny, thin, leathery, cordate with long tapering ends (drip tip), reticulately venated, and sized around 10-17 $\times 8-12 \mathrm{~cm}$ [Fig. 6(c)]. The leaves are rich in protein and contain various amino acids, carbohydrates, sterols, tannic acid, triterpenes, hydrocarbons, and fatty alcohols and utilized for treating wounds, asthma, cough, toothache, hematuria, diarrhea, migraine, gastric, ocular, and skin disorders in folk medicine. The leaves exhibit anti-inflammatory, antivenin, analgesic, antioxidant, antibacterial, antifungal, wound healing, and laxative activities. The leaves are hand stitched into plates for serving food [Fig. 6(d)]. The ingredients present in the leaf plates activates the red blood cells, fights against jaundice, and protects from throat infections (Rutuja et al. 2015; Singh 2010; Somaaya, 2018; Today 2017).

\section{Ficus virens}

The white fig is known as juvvi, plaksa, pilkhan, etc. in various Indian languages. It is a medium sized, strangling fig, which belongs to the family Moraceace and found in India, Malaysia, Australia, and Southeast Asia. The tree is a preferred habitat for thousands of birds, as it supplies soft fruits during the dry and difficult summer months of April and May, and the same is mentioned in the Indian moral story book, Panchatantra. The juvvi tree is worshipped by the devotees at Medaram village during the Sammakka-Saramma Jatara, the largest tribal festival of Telangana state. The leaves are ovate, leathery with whitish prominent mid rib, and sized around 5-20 × 3-6 cm [Fig. 6(e)]. The leaves contain phenolics, tannins, flavonoids, and coumarins and exhibit antiviral, hypolipidemic, antiulcer, and antioxidant activities. The practice of eating food on juvvi leaf leaves removes pitta dosha, excessive heat generated in the body, purifies the blood, and acts as a coolant [Fig. 6(f)] (Orabi and Orabi 2016).

\section{Ficus auriculata}

The elephant ear fig is a small, evergreen, semi deciduous tree and belongs to the family Moraceace. It is found all over Asia, especially in India, Bhutan, Nepal, Myanmar, Pakistan, China, Vietnam, Thailand, Malaysia, and Brazil. In India, they are distributed in the states of
Manipur, Meghalaya, Assam, Karnataka, and Himachal Pradesh. The leaves are big, cordate, undulate, obtuse, gritty, sand paper textured, heavily veined (5-7) from the leaf base and sized around 30-44 $\times 40-45 \mathrm{~cm}$. The leaves contain phenolics, tannins, steroids, flavonoids, glycosides, saponins and triterpenoids and used for treating diabetes, diarrhoea, dysentery, and wounds. They demonstrate antibacterial, anti-inflammatory, hepatoprotective, and antioxidant activities. They are made as plates by stitching 3-4 leaves together and used for taking food during the festive banquets in the villages. The leaves are also used as fodder during winters, a favorite food for the cattle (George et al. 2016; Krishnan, 2015).

\section{Macaranga peltata}

It is known as vatta, chamdakala, chanda, and boddi in various Indian languages. It is a medium sized, dioecious tree which belongs to the family Euphorbiaceae and widely distributed in India, Sri Lanka, Myanmar, and Thailand. It is found in the states of Karnataka, Kerala, Tamil Nadu, Maharashtra, Goa, Sikkim, and West Bengal, in evergreen and semi-evergreen forests. The leaves are peltate, characterized by attachment of leaf stalk on the lower leaf surface and lamina sized around 20-50 $\times$ $12-25 \mathrm{~cm}$. The leaves are abundant source of flavonoids, stilbenes, tannins, terpenes, coumarins, steroids, and polyphenols and show anti-inflammatory, anticancer, antimicrobial, and antioxidant properties. Because of the large size of the lamina, plates made out of these leaves are used for serving meal. In the villages of Kerala state, grandmothers use the abundantly available vatta leaves from their backyard for serving breakfast such as upma to the children. These leaves are used as wraps in Kerala for the steam cooking of the sweet dishes ilayappam and $a d a$, as they provide an ideal platform for dough spreading and impart distinctive flavor to the dishes. The nitrogen- and potassium-rich leaves decompose very quickly and improve the nutrient content in the soil (Almedia 2003; Magadula 2014)

\section{Curcuma longa}

The turmeric is an herbaceous, rhizomatous, short pseudo stemmed; perennial plant which belongs to the family Zinziberaceae. It is native to Indian subcontinent, Australia, and Southeast Asia and used in Ayurveda, Siddha and Unani medicine for thousands of years. It is cultivated in Telangana, Andhra Pradesh, Tamil Nadu, Maharashtra, and West Bengal states of India. The leaves are alternately arranged, large, tufted, oblong, narrow tipped, and the size of the leaf blade is around 76$115 \times 38-45 \mathrm{~cm}$ [Fig. 7(a)]. The leaves are rich sources of carotenoids, flavonoids, and essential oils and demonstrate antibacterial, antifungal, antidermatophytic, antioxidant, anticancer, noortropic, and immunomodualting 

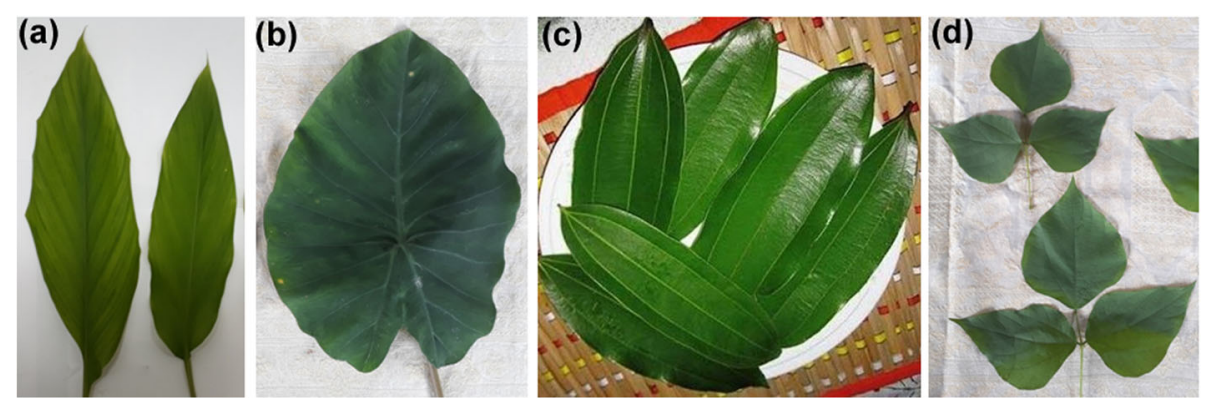

Fig. 7 a The leaves of turmeric, C. longa, (b) the leaves of taro, C. esculenta (c) the leaves of therali, C. malabathrum and (d) the leaves of Indian bean L. purpureus

activities. The leaves are also one of the Navapatrika, representing goddess Durga. In the western Indian states of Maharashtra, Goa, and Karnataka, people use turmeric leaves as food wraps during the steam cooking of sweet dish named patoli, served as a naivedyam to god Ganesha during the festival of Ganesh Chaturthi. It provides a distinctive turmeric flavor to the dish, and the tasty dish enhances the disease resistance during spring season (Bhardwaj et al. 2011; Patoli 2018).

\section{Colocasia esculenta}

The taro is commonly known as kachu, arvi, and chema in Indian languages. It is a tropical, perennial, rhizomatous plant which belongs to the family Araceae and native to southern India and Southeast Asia. It is cultivated for edible corms, leaves, and petioles in the Indian states of Mizoram, Assam, Manipur, Himachal Pradesh, Karnataka, Maharashtra, Goa, Gujarat, Kerala, Tamil Nadu, Andhra Pradesh, Telangana, West Bengal, Bihar, Odisha, and Uttarakhand. The leaves are triangular-ovate, cordate, bright green, mucronately tipped, and sized around $20-150 \times 24.8 \mathrm{~cm}$ [Fig. 7(b)]. The leaves are good source of proteins, ascorbic acid, vitamin A, B complex vitamins, dietary fiber, phosphorous, zinc, iron, potassium, copper, and manganese. The leaves show anti-inflammatory and analgesic properties. As the leaves contain calcium oxalate crystals in the form of raphides, it is customary to boil or steam them with tamarind during cooking. The leaves are extensively used as food wraps during the steam cooking and oil frying of dishes such as patrode and alu chi wadi in the states of Maharashtra, Karnataka, and Goa, respectively. The leaves are also part of Navapatrika, representing the goddess Kalika (Bhardwaj et al. 2011; Patoli 2018).

\section{Cinnamomum malabatrum}

The wild cinnamon is a rarely cultivated, moderately sized tree popularly known as therali, vazhana, and malabathrum in Indian languages. It belongs to the family Lauraceae and considered as a native plant of Western Ghats, tropical and subtropical Himalayas, Uttar Pradesh, East Bengal; Khasia and Jaintia hills of Assam, and Meghalaya states of India. It is usually grown in the backyards of countryside houses, through seeds and root suckers. The tree was mentioned under the name Kattukaruva in the seventeenth century treatise Hortus Malabaricus (garden of Malabar) that deals with the flora of Western Ghats region, covering the Indian states of Kerala, Karnataka, and Goa. The leaves are fragrant, three ribbed, elliptical, glabrous, and sized around 10-30 × 3-9 cm [Fig. 7(c)]. The fragrance is due to the constituents such as flavonoids and terpenoids; i.e., eugenol, camphor, benzaldehyde, and cinnamic aldehydes. A sweet dish known as therali appam, stuffed and steam cooked in the wrapped cones made up of therali leaves, is offered to the goddess Attukal Bhagavathi located in temple at Thiruvananthapuram, Kerala during the festival Attukal Pongala. The leaves are sold in the local markets during festive seasons, as the leaves infuse characteristic flavor and fragrance to the dumpling while steam cooking (http://www.roshniskitchen.com/ 2012/03/therali-appam-attukal-pongala.html, 2013).

\section{Pandanus amaryllifolius}

The screw pine is commonly known as pandan, mundaka, kedige, mundig, rampe, and kaitha in various Indian languages. It is an upright, sterile, tropical shrub with woody aerial roots and belongs to the family Pandanaceae. It is globally distributed in Indo-Malaysia and cultivated in Karnataka, Maharashtra, Kerala states and Andaman and Nicobar Islands along the beaches, river banks and ponds of coastal areas. The leaves are fragrant, oblong, caudate, prickly on the margins and midrib; glossy green, flaccid, keeled beneath, entirely margined and sized around $25-75 \times 2-5 \mathrm{~cm}$. The leaves are used for treating fever, indigestion, flatulence, skin diseases, and rheumatoid pains and exhibit diuretic, cardiotonic, hypoglycemic, antiviral and antioxidant properties. The leaves are known to contain aromatic compound 2-acetyl-1-pyrroline, which gives the characteristic aroma to white bread, jasmine rice, kaorimai rice 
and basmati rice. The leaves are used as food flavoring and coloring agent to non-scented rice. The leaves are rolled, weaved like a ribbon and made into cylindrical containers, after blanching. The cylindrical leaf molds are used as food wraps during steam cooking of cylindrical $i d l i$ known as mude during rainy season in Dakshina Kannada district of Karnataka state and Krishna Janmastami festival. In addition to its medicinal values, the leaves incorporate taste and aroma to the dish during steam cooking. The leaves are also used for making baskets and sleeping mats (Bhagya et al. 2013; Liew 2013)

\section{Lablab purpureus}

The Indian bean is known as chikkudu, sheem, avara, etc. in Indian languages. It is a twinning climber, which belongs to the family Fabaceae and originated in India or Southeast Asia. It is commonly distributed in many tropical and subtropical countries. The leaves are pinnate, trifoliate, broad oval in shape and measures around 7.6-15.2 cm [Fig. 7(d)]. The leaves are rich in proteins, iron, zinc; and contain sugars, alcohol, phenols, steroids, alkaloids, flavonoids, saponins, terpenoids, glycosides, pigments, tannins and coumarins. The leaves show antidiabetic, antibacterial, antifungal and cytotoxic activities. The Sun god is worshipped on the festival day of Ratha Saptami and ksherannam; a sweet is offered to Sun god as naivedyam in 7 pairs of chikkudu leaves (Al-Snafi 2017; Krishna 2011; Madhuri Devi and Vinitha 2011).

\section{Borassus flabellifer}

The palmyra palm is known as thati, toddy, tala, tad, etc. in various Indian languages. It is a tall, single trunked, unbranched, dioecious palm and belongs to the family Aracaceae. It is grown widely in tropical areas of India, Bangladesh, Nepal, Thailand, Malaysia, Philippines, Myanmar, Sri Lanka and Africa. It is found in the states of Andhra Pradesh, Telangana, Tamil Nadu and Maharashtra as groves. It is the official state tree of Tamil Nadu state. The trunk top is crowned with large number of fan shaped; rigid leaves sized around $3 \times 3 \mathrm{~m}$ with a diameter of around 1-1.5 $\mathrm{m}$ and divided into lance shaped segments folded along the mid vein [Fig 8(a)]. The leaves possess phenolics, flavonoids, glycosides, tannins, proteins, steroids, triterpenoids, carbohydrates and fats and exhibit antibacterial, antifungal, antihelminthic and antioxidant activities.

The leaves are extensively used as fuel, thatching material and weaved into baskets, mats, boxes, hats, fans, toys and country umbrellas [Fig 8(b)]. The leaves known as tala patra are used as writing material for manuscripts in ancient India. The fiber obtained from the leaves is used to make strings, straps and ropes. A single young leaf which is circularly folded and secured with leaf fiber is used for packing and parceling meat. The same is used for parceling munjelu, jelly endosperm from the seeds of unripe fruits and burra gunju, a white, sweet, seed kernel from the germinating seeds of toddy tree. Also, the tender folded leaf is used for drinking kallu, a fermented sugary sap beverage obtained from the young inflorescence of the toddy tree. The circularly folded and sealed tender leaf is also used for steam cooking of marinated chicken in pots at roadside eateries in the Chittur district of Andhra Pradesh state. Sometimes the farmers use the leaf as a dining plate for eating food in the fields, in the absence of other broad leaves. The separated veins from the leaves are also used for anchoring and carrying the fish and as meat skewers. The baskets made with toddy leaves are used for packing sugarcane and toddy jaggery [Fig 8(c)]; mangoes, coconuts, groceries, flowers and wooden children toys. The circular stands made out of leaves are used as stands for supporting and balancing circular hot utensils such as pots (Jamkhande et al. 2016).

\section{Conclusions}

In comparison with plastic plates, the leaf plates and cups offer many advantages such as renewability, biodegradability, non-toxicity and antioxidant abundance; in addition to their religious, medicinal, socio-economic importance in Indian culture. It is evident that there is large scope in leaf plate technology in terms of raw material quality, design improvement, product range, production process and
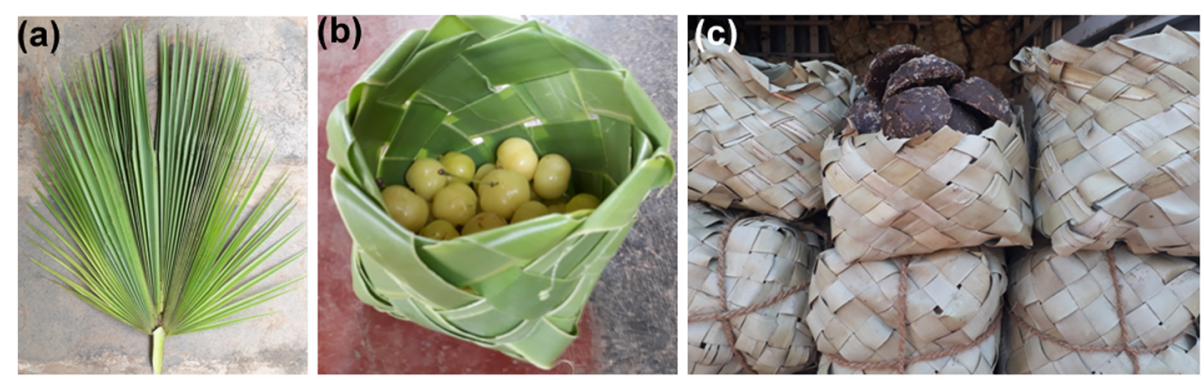

Fig. 8 a The leaves of thati, B. flabellifer, (b) hand oven leaf basket of made from thati is used for storing star gooseberry fruits and (c) packing of toddy jaggery in leaf baskets of thati 
marketing. For example, design of popcorn buckets and leak proof soft drink glasses in movie theaters and multiplexes is much needed (Singh 2018). Various governmental agencies including forest development, rural development, tribal development, banking, small scale industry, handicraft, textile and handloom sectors should coordinate with the stakeholders of the leaf trade for their participation in fairs, exhibitions, gift fairs and handicraft melas organized at local, state, national and international levels for market expansion. In addition to national market, a huge demand exists in international market for disposable, biodegradable leaf plates. However, the products should meet the stringent quality standards set by the regulating bodies. To sustain the practice of using leaf plates in our daily routine and discourage plastic plate usage; necessary regulations should be imposed by the government bodies including the state pollution control boards, local municipal corporations and gram panchayats. It should be made obligatory to use disposable leaf plates at restaurants, hotels, roadside eateries, canteens, street food stalls, take away food joints, temples, gurudwaras, traditional feasts, religious feasts, wedding ceremonies, etc. Also, its use should be made mandatory in official meetings, gatherings and parties; and in government departments like railway catering, temple endowment boards, etc. For instance, meal known as Anna Prasadam is served daily to nearly $160,000-200,000$ pilgrims at different locations of the temple by Sri Venkateswara Annaprasadam trust run by Tirumala Tirupati Devasthanam. Law enforcement such as imposed ban on single use plastic definitely meets the Indian government directives of Swachh Bharat and Swasth Bharat missions launched by Ministry of Drinking Water and Sanitation and Ministry of Health, respectively. In addition, a chapter on leaf plates should be incorporated in the curriculum of the school children and college students to realize their importance and significance in Indian culture.

\section{Abbreviations}

EDC: endocrine disrupting chemicalPVCpolyvinyl chloridePOPspersistent organic pollutantsLDPElow density polyethyleneBISBureau of Indian StandardsGSTgoods and services taxNGOsnon-governmental organizationsNRCBNational Research Centre for Banana

\section{Acknowledgements}

The author would like to thank Dr. Athyala Christian Sahayam, Head, Bulk Analysis Section (BAS) and Dr. Sunil Jai Kumar, Head, NCCCM/BARC for their constant encouragement and support throughout the study.

\section{Author's contributions}

The author alone involved in data collection, compilation, writing and interpretation during the manuscript preparation. The author read and approved the final manuscript.

\section{Funding}

No funding source to declare.

Availability of data and materials Not applicable.
Ethics approval and consent to participate

Not applicable.

\section{Consent for publication}

Not applicable.

\section{Competing interests}

The author declares that she has no competing interests.

Received: 19 September 2019 Accepted: 14 November 2019

Published online: 27 December 2019

\section{References}

Abraham P (2016) Europe calling for siali leaf plates. The Telegraph. Accessed 14th Aug 2018

Almedia MR (2003) Flora of Maharashtra In: Thomas Paul Almeida for Blatter Herbarium SXsC (ed), Volume 4. Orient Press, Mumbai., p 335

Al-Snafi AE (2017) The pharmacology and medical importance of Dolichos lablab (Lablab purpureus)- A review. IOSR Journal Of Pharmacy 7:22-30

Bhagya B, Ramakrishna A, Sridhar KR (2013) Traditional seasonal health food practices in southwest India: Nutritional and medicinal perspectives Nitte University Journal of Health Science 3

Bhardwaj KS, Bhardwaj RS, D R, N G (2011) Curcuma longa leaves exhibits a potential antioxidant, antibacterial and immunomodulating properties 3:9

Chatterjee P, Chakraborty B, Nandy S, Dwivedi A, Datta R (2012) Pterospermum acerifolium Linn. : A comprehensive review with significant pharmacological activities. Internation Journal of Pharmacy \& Life Sciences 3:1453-1458

Chaudhari SG, Mishra PA, Adam A, Chaudhari H, Desai J, Duvvuri P, Shendkar A (2014) A pharmacogntical and pharmcological review of Ficus bengalensis. International Journal of Pharmaceutical Archive 3:296-301

Chaudhary S, Alok S, Jain SK, Chanchal D, Dongray A (2015) Phytopharamacology and pharmacognostic properties of Ficus benghalensis-A review, International Journal of Pharmacognosy and Phytochemical Research. 2:560-569

Choe J-H et al (2011) Oxidative and color stability of cooked ground pork containing lotus leaf (Nelumbo nucifera) and barley leaf (Hordeum vulgare) powder during refrigerated storage. Meat Science 87:12-18

Chouhan R, Saklani S (2013) Bauhinia vahlii: a plant to be explored. International Reaserch Journal of Pharmacy 4:5-9.

Culinary creations-Jackfruit idli. (2018). Accessed 21st August 2018

Dash DM (2015) Mahaprasad Odisha Review July:34-39

George M, Joseph L, Paul NM (2016) Ficus auriculata; A Pharmacological update. International Journal of Current Research and Academic Review 4:26-31

Goyal N (2018) What type of plant leaves should I use to make plates? Answer Wiki Accessed 14th August 2018

Hebbar JV (2015) Lotus - Nelumbo nucifera Benefits, side effects, research. Accessed 7th September 2018

Hegde S, Nair LP, Chandran H, Irshad H (2018) Traditional Indian way of eatingan overview Journal of Ethnic Foods 5:20-23

http://annavaramdevasthanam.nic.in/prasadam.htm (2018) Prasadam. Accessed 26 Sept 2018

http:/www.roshniskitchen.com/2012/03/therali-appam-attukal-pongala.html (2013) Therali Appam - Attukal Pongala. Prathibha

https:/en.wikipedia.org/wiki/Plastic (2018) Plastic. Wikipedia,

Imam MZ, Akter S (2011) Musa paradisiaca L. and Musa sapientum L. : A phytochemical and pharmacological review Journal of Applied Pharmaceutical Science 01:14-20

Jamkhande PG, Suryawanshi VA, Kaylankar TM, Patwekar SL (2016) Biological activities of leaves of ethnomedicinal plant, Borassus flabellifer Linn. (Palmyra palm): An antibacterial, antifungal and antioxidant evaluation Bulletin of Faculty of Pharmacy, Cairo University 54:59-66

Kapoor J (2018) Kanak Champa is also popular as the 'dinner plate tree' in Punjab, and here's why. Chandigarh

Kothapalli PK, Jagadeesh S, Sanganal NBS (2014) Phytopharmacology of Ficus bengalensis-A review, Asian Journal of Pharmocology and Research 4:201204

Krishna N (2011) Aaroghyam bhaskadichcheth Vijnana Vihara 29:6

Krishnan B (2015) Ficus auriculata - Elephant ear fig tree Accessed 31st August 2018.

Leaf cups (2018) Eenadu. Vasundhara Publications, Hyderabad

Liew PS (2013) Pandanus amaryllifolius-The only Pandanus with fragrant leaves. Accessed 01st Janauary 2019 
Madhuri Devi K, Vinitha T (2011) Sun-The god of energy Vijnana Vihara 29:7 Magadula JJ (2014) Phytochemistry and pharmacology of the genus Macaranga: A review. Journal of Medicinal Plant Research 8:489-503

Mengi SA, Deshpande SG (1999) Anti-inflammatory activity of Butea frondosa leaves, Fitoterapia 70:521-522

Merish S, Tamizhamuthu M, Walter TM (2014) Review of Shorea robusta with special reference to traditional Siddha medicine, Research and Reviews. Journal of Pharmocognost and Phytochemistry 2:5-13

Mishra, A (2014) The aroma of a flavourful leaf different taste.

Muhammad A, Mudi SY (2011) Phytochemical screening and antimicrobial activities of Terminalia catappa, leaf extracts Biokemistri 23:35-39

Nidavani RB, A MM (2014) Pharmacology of Tectona grandis Linn.: Short review. International Journal of Pharmacognosy and Phytochemical Research 6:86-90

Orabi MAA, Orabi EA (2016) Antiviral and antioxidant activities of flavonoids of Ficus virens: Experimental and theoretical investigations. Journal of Pharmacognosy and Phytochemistry 5:120-128

Patoli (2018) Eenadu. Vasundhara Publications, Hyderabad

Prasad KS (2018) Moduga aaku rottelu. Vasundhara Publications, Hyderabad, Eenadu

Prasad PW, Subhaktha PKJP, Narayana A, Mruthyumjaya Rao M (2006) Palasa (Butea monosperma (Lamk.)Taub.) and its medico-history study. Bulletin of the Indian Institute of History of Medicine (Hyderabad) 36:117-132

Rai A, Singh AK, Pandey VC, Ghosal N, Singh N (2016) The importance of Butea monosperma for the restoration of degraded lands. Ecological Engineering 97:619-623

Raj RD (2018) Advanced leaf plate technology. Raj, R. D, Hyderabad

Rajkumar S (2014) Turning over a new leaf. N. Ram, Chennai

Raju BP (2018) Chiru dhanyalatho chesin vasenapoli thinnara ? Vasundhara Publications, Hyderabad

Rutuja RS, Shivsharan U, Shruti AM (2015) Ficus religiosa (Peepal): A Phytochemical and pharmacological review. Interantional Journal of Pharmaceutical and Chemical Sciences 4:360-370

Sachan K, Singh PK, Ashwlayan VD, Singh R (2014) Evaluation of hepatoptrotective activity of Tectona grandis Linn. International Journal of Pharmaceutical and Medicinal Research 2:105-108

Sahu MC, Padhy RN (2013) In vitro antibacterial potency of Butea monosperma Lam. against 12 clinically isolated multidrug resistant bacteria, Asian Pacific Journal of Tropical Disease 3:217-226

Sahu P (2015) Sal and siali leaves sustaining tribal Orissa. Down To Earth, Sarin D (2017) This is why you must eat on a banana leaf. NDTV Convergence,

Seetharaman G (2019) How plastic ban will affect businesses and consumers The Economic Times

Selvakumar R (2018) What type of plant leaves should I use to make plates? Answer Wiki Accessed 14th August 2018

Shashikumar SDJ, Manjunatha K, Anantachar M (2016) Physical properties of arecanut sheath, International Journal of Agriculture Sciences 8:3378-3380

Shriya M (2009) A document on the Siali leaf-plate making activity of Kandhamal district, Orissa. Pradan. Accessed 27th August 2018

Sidhu AS (2012) Jackfruit improvement in the Asia-Pacific region-A status report Asian Pacific Association of Agricultural Researc Instituitions (APAARI). Bangkok, Thailand, pp 1-182

Singh D (2018) Sal leaves and Sabai grass craft Accessed 19th November 2018

Singh SH (2010) The century-old fig tree in Jannaram mandal has became a toast of conservationists in Adilabad. N. Ram, Kasturi and Sons Ltd., Chennai

Somaaya B (2018) I am peepala, the king of trees. Accessed 27th Aug 2018.

Somayaji A, Hegde K (2016) A review on phrmacological profile of Butea monosperma. International Journal of Phytopharmacology 7:237-249

Swathi D, Jyothi B, Sravanthi C (2011) A Review: Pharmacognostic studies and pharmacological actions of Musa Paradisiaca, International Journal of Innovative Pharmaceutical Research 2:122-125

Tangar E (2017) While India is getting over its traditional leaf plate, the world seems to be catching on. ScoopWhoop Media Pvt. Ltd. Accessed 14th August 2018

Tankha M (2002) Fabulous food on banana leaves. N. Ram, Chennai

Tanwar M, Tanwar B, Tanwar RS, Kumar V, Goyal A (2018) Himachali dham: Food, culture, and heritage, Journal of Ethnic Foods 5:99-104

Terças AG et al (2017) Phytochemical characterization of Terminalia catappa Linn. extracts and their antifungal activities against Candida spp, Frontiers in Microbiology 8. https://doi.org/10.3389/fmicb.2017.00595

Today N (2017) Patraphalam praptirastu, District edn. Vasundhara Publications, Hyderabad
Tortora K (2014) 16 step puja worship in Hinduism.

Uma S (2008) Farmer's knowledge of wild Musa in India Food and Agriculture Organization of the United Nations, Rome TC/D/10548E/2/12.08/500

Uma S, Selvarajan R, Sathiamoorthy S, Ramesh Kumar A, Durai P (2018) Evaluation of banana germplasm for the leaf industry and for suitability to different growing environments in India PGR Newsletter:26-32

Vasundhara (2018) A short report on sal leaf trade. Accessed 21st August 2018

Venkata Ramana M (2018) Chethulu kalaka munde aakulu pattukundam ! Vasundhara Publications Ltd., Hyderabad

Vora SB, Parasar GC (1969) Phytochemical studies on Ficus bengalensis Linn (Preliminary report), Indian Journal of Physiology and Pharmacology 13:143-145

\section{Publisher's Note}

Springer Nature remains neutral with regard to jurisdictional claims in published maps and institutional affiliations.

\section{Submit your manuscript to a SpringerOpen ${ }^{\circ}$ journal and benefit from:}

- Convenient online submission

- Rigorous peer review

- Open access: articles freely available online

- High visibility within the field

- Retaining the copyright to your article

Submit your next manuscript at $\boldsymbol{\nabla}$ springeropen.com 